\title{
ZNAČAJ DRŽAVNE REVIZORSKE INSTITUCIJE
}

Rezime
Državna revizorska institucija (Institucija) je najviši organ revizije javnih sredstava u Republici Srbiji. Osnovana je 2005. godine Zakonom o Državnoj revizorskoj instituciji. Državna revizorska institucija je samostalan i nezavisan državni organ. Za obavljanje poslova iz svoje nadležnosti Institucija je odgovorna Narodnoj skupštini Republike Srbije. Poslove iz svoje nadležnosti obavlja na osnovu Ustava Republike Srbije, Zakona o Državnoj revizorskoj instituciji i Poslovnika Državne revizorske institucije, koji u skladu sa Zakonom, bliže uređuje način i postupak po kome Institucija vrši svoju nadležnost revizije, način obezbeđivanja javnosti rada, odlučivanja i druga pitanja utvrđena Zakonom koja su od značaja za rad Institucije. Institucija ima predsednika Institucije, potpredsednika, Savet, revizorske službe i prateće službe.

Ključne reči: Državna revizorska institucija, revizija, etički kodeks državnih revizora.

\section{UVOD}

Revizorskim službama rukovode vrhovni državni revizori. Rad pratećih službi Institucije usklađuje sekretar Institucije. Delokrug i način obavljanja poslova službi Institucije, unutrašnja organizacija i sistematizacija radnih mesta bliže su uređeni aktom Institucije - Pravilnikom o unutrašnjoj organizaciji i sistematizaciji radnih mesta, koji na predlog predsednika Institucije donosi Savet.

Etički kodeks državnih revizora i drugih zaposlenih u Državnoj revizorskoj instituciji bliže uređuje etička načela, opšteprihvaćena pravila ponašanja i profesionalne standarde kojih su dužni da se pridržavaju funkcioneri, državni revizori i drugi zaposleni u Državnoj revizorskoj instituciji. Pravila ovog kodeksa dužni su da se pridržavaju i spoljni stručnjaci angažovani u Državnoj revizorskoj instituciji u vršenju poslova iz njene nadležnosti. Državni revizori i drugi zaposleni dužni su da poštuju primenjuju Zakon o Državnoj revizorskoj instituciji, standarde revizije INTOSAI (Međunarodna organizacija vrhovnih revizorskih institucija), INTOSAI Etički kodeks i ovaj kodeks.

\section{ISTORIJAT DRI}

Državna revizorska institucija, najviši organ revizije javnih sredstava u Republici Srbiji, osnovana je Zakonom o Državnoj revizorskoj instituciji 2005. godine. Naredne, 2006. godine, Državna revizorska institucija je prepoznata kao ustavna kategorija. U delu Ustava Republike Srbije koji se odnosi na ekonomsko uređenje i javne finansije, navedeno je da „izvršavanje svih budžeta kontroliše Državna revizorska institucija“(član 92), kao i „Državna revizorska institucija je najviši državni organ revizije javnih sredstava u Republici Srbiji, samostalna je i podleže nadzoru Narodnoj skupštini, kojoj i odgovara“ (član 96).

Na petoj sednici Odbora za finansije Narodne skupštine, koja je održana 6. septembra 2007. godine, članovi Odbora su glasanjem utvrdili listu kandidata Saveta Državne revizorske institucije koju su predložili Narodnoj skupštini na usvajanje. Za predsednika Saveta, predložen je Radoslava Sretenovića, za potpredsednika Ljubica Nedeljković, a za članove Saveta predloženi su Zoran Tamaš, Ljiljana Dmitorvić-Šaponja i Natalija Ćatović. Na sednici Narodne skupštine koja je održana 24. septembra 2007. godine, Narodna skupština izabrala je predsednika, potpredsednika i članove Saveta Državne revizorske institucije, najvišeg organa Institucije.Za predsednika Saveta izabran je Radoslav Sretenović, za potpredsednika Ljubica Nedeljković, za članove Zoran Tamaš, Ljiljana Dmitrović Šaponja i Natalija Ćatović. Izbor članova Saveta označava i početak rada Institucije.

Godinu dana nakon izbora, Ljiljana Dmitrović Šaponja je podnela ostavku na mesto člana Saveta. $\mathrm{Na}$ 16. sednici Odbora za finansije, koja je održana 21. januara 2009. godine, članovi Odbora su usvojili većinom glasova predlog odluke o izboru Danke Aksentijević za člana Saveta Državne revizorske institucije. Narodna skupština, na sednici koja je održana 18. marta 2009. godine, je donela odluku i za člana Saveta izabrala Danku Aksentijević.

\footnotetext{
${ }^{4}$ Master studije Javne finansije, Vojna akademija, Beograd, pekovicj@yahoo.com
} 
Ubrzo nakon osnivanja, u novembru 2008. godine, Državna revizorska institucija postala je punopravna članica Međunarodne organizacije vrhovnih revizorskih institucija (INTOSAI). Deo Evropske organizacije vrhovnih revizorskih institucija (EUROSAI) Državna revizorska institucija je postala punopravnim članstvom 23. juna 2009. godine.

Radi obavljanja poslova iz nadležnosti Institucije, odnosno bližeg uređenja postupka revizije, Narodna skupština je usvojila 2009. godine Poslovnik o Državnoj revizorskoj instituciji 2009. godine. Ipak, među najvažnijim datumima od osnivanja Institucije svakako je 27. novembar 2009. godine. Toga dana je Državna revizorska Institucija predala Narodnoj skupštini prvi izveštaj o reviziji finansijskih izveštaja i pravilnosti poslovanja. Izveštaj se odnosio na završni račun budžeta Republike Srbije za 2008. godinu. Naredne, 2010. godine, Državna revizorska institucija je postala članica Mreže vrhovnih revizorskih institucija država kandidata i potencijalnih kandidata za članstvo u Evropsku uniju. Prvi Strateški plan Državne revizorske institucije za period 2011-2015. godine donet je 2011. godine.

Na petoj sednici Odbora za finansije, republički budžet i kontrolu trošenja javnih sredstava, koja je održana 17. septembra 2012. godine, članovi Odbora su razmotrili kandidature i utvrdili listu kandidata za predsednika, potpredsednika i članove Saveta Državne revizorske institucije. Kandidat za predsednika Saveta bio je Radoslav Sretenović, za potpredsednika Bojana Mitrović, a za članove Saveta Natalija Ćatović, Gordana Tišma i Miroslav Mitrović. Novi saziv Saveta Državne revizorske institucije, izabran je 25. septembra 2012. godine. Za predsednika Saveta, po drugi put na tu funkciju, Narodna skupština izabrala je Radoslava Sretenovića, za potpredsednika Bojanu Mitrović, za članove Nataliju Ćatović, Gordanu Tišmu i Miroslava Mitrovića.

Posebno mesto u razvoju Državne revizorske institucije svakako zauzima i objavljivanje prvog izveštaja o reviziji svrsishodnosti poslovanja. Izveštaj o reviziji pod nazivom „Upravljanje službenim vozilima direktnih korisnika budžeta Republike Srbije“ predstavljen je javnosti 27. juna 2014. godine. Institucija se suočava sa brojnim problemima koji otežavaju njen rad i funkcionisanje. Jedan od njih odnosi se na poslovni prostor. Institucija i dalje ne raspolaže adekvatnim, jedinstvenim prostorom za rad. Zbog toga Institucija ne može da realizuje svoj kadrovski plan, odnosno zbog nedovoljnih prostornih kapaciteta dinamika prijema novih kadrova ne odgovara potrebama Institucije.

\section{ULOGA, VIZIJA I MISIJA DRI}

Državna revizorska institucija, kao najviši organ revizije javnih sredstava, u okviru svoje nadležnosti, obavlja sledeće poslove:

- planira i obavlja reviziju, u skladu sa Zakonom o Državnoj revizorskoj instituciji;

- donosi podzakonske i druge akte radi sprovođenja Zakona o Državnoj revizorskoj instituciji;

- $\quad$ podnosi izveštaje Narodnoj skupštini Republike Srbije i skupštinama lokalnih vlasti;

- zauzima stavove i daje mišljenja kao i druge oblike javnih saopštenja u vezi sa primenom i sprovođenjem pojedinih odredaba Zakona o Državnoj revizorskoj instituciji;

- po potrebi i u skladu sa svojim mogućnostima, pruža stručnu pomoć Skupštini, Vladi Republike Srbije (u daljem tekstu: Vlada) i drugim državnim organima o pojedinim značajnim merama i važnim projektima, na način kojim se ne umanjuje nezavisnost Institucije;

- može da daje savete korisnicima javnih sredstava;

- može davati primedbe na radne nacrte predloga zakonskih tekstova i drugih propisa i može davati mišljenja o pitanjima iz oblasti javnih finansija;

- može da daje preporuke za izmene važećih zakona na osnovu informacija do kojih je došla u postupku obavljanja revizije, a odnose se na to da proizvode ili mogu proizvesti negativne posledice ili dovode do neplaniranih rezultata;

- usvaja i objavljuje standarde revizije u vezi sa javnim sredstvima koji se odnose na izvršavanje revizijske nadležnosti Institucije, na priručnike za reviziju i na drugu stručnu literaturu od značaja za unapređenje revizorske struke;

- utvrđuje program obrazovanja i ispitni program za sticanje zvanja državni revizor i ovlašćeni državni revizor, organizuje polaganje ispita za sticanje revizorskih zvanja državni revizor i ovlašćeni državni revizor i vodi Registar lica koja su stekla ova zvanja;

- utvrđuje kriterijume i vrši nostrifikaciju stručnih zvanja iz nadležnosti Institucije stečenih u inostranstvu;

- sarađuje sa međunarodnim revizorskim i računovodstvenim organizacijama u oblastima koje se odnose na računovodstvo i reviziju u okviru javnog sektora;

- obavlja druge poslove utvrđene Zakonom o Državnoj revizorskoj instituci.

Državna revizorska institucija je prepoznatljiva, pouzdana, nezavisna institucija koja ima za cilj da doprinosi parlamentarnoj kontroli i dobrom upravljanju u javnom sektoru.

Svrha vizije je da obezbedi pravac delovanja Državne revizorske institucije. U viziji Državne revizorske institucije je odražen konsenzus postignut nakon konsultacija sa internim i eksternim 
stejkholderima. Na taj način, vizija daje svrhu i smisao zajedničkih nastojanja Državne revizorske institucije i eksternih stejkholdera u promovisanju dobrog upravljanja.

Državna revizorska institucija je najviši, nezavisan, državni organ revizije javnih sredstava u Republici Srbiji, koji pruža profesionalno uveravanje Narodnoj skupštini i građanima Republike Srbije da se javna sredstva koriste efektivno, efikasno i ekonomično.

Misija kratko i jasno predstavlja razloge našeg postojanja, funkcije koje bi trebalo da ispunimo, našu primarnu ulogu i metode pomoću kojih nameravamo da je ostvarimo.

\section{PREDMET I SUBJEKTI REVIZIJE DRI}

Zakonom utvrđen je predmet revizije. Shodno Zakonu sva javna sredstva u Republici, odnosno sva primanja i izdaci u skladu sa propisima o budžetskom sistemu, svi finansijski izveštaji, finansijske transakcije, obračuni, analize i druge evidencije i informacije subjekata revizije, pravilnost poslovanja subjekata revizije u skladu sa zakonom, svrsishodnost raspolaganja javnim sredstvima, sistem finansijskog upravljanja i kontrole budžetskog sistema, sistem internih kontrola, interne revizije, predstavljaju predmet revizije.

Predmet revizije su akta i radnje subjekta revizije koje proizvode ili mogu da proizvedu finansijske efekte na primanja i izdatke korisnika javnih sredstava, imovina države, zaduživanja i davanja garancija, kao i svrsishodna upotreba sredstava kojima raspolažu subjekti revizije, ali i pravilnost rada organa rukovođenja, upravljanja i drugih odgovornih lica nadležnih za planiranje, izvođenje i nadzor poslovanja korisnika javnih sredstava.

Subjekti revizije su svi korisnici javnih sredstava, odnosnodirektni i indirektni korisnici budžetskih sredstava, organizacije obaveznog socijalnog osiguranja (Fond za penzijsko i invalidsko osiguranje, Republički fond za zdravstveno osiguranje, Nacionalna služba za zapošljavanje), budžetski fondovi osnovani posebnim zakonom ili podzakonskim aktom, radi ostvarivanja cilja koji je predviđen posebnim republičkim, odnosno lokalnim propisom ili međunarodnim sporazumima, tako da su subjekti revizije, praktično, svi oni korisnici koji čine budžetski sistem Republike.

Subjekti Državne revizije:

- Direktni i indirektni korisnici budžetskih sredstava Republike, teritorijalnih autonomija i lokalnih vlasti;

- Organizacije obaveznog socijalnog osiguranja;

- Budžetski fondovi osnovani posebnim zakonom ili podzakonskim aktom;

- Narodna banka Srbije u delu koji se odnosi na korišćenje javnih sredstava i na poslovanje sa državnim budžetom;

- Javna preduzeća, privredna društva i druga pravna lica koje je osnovao direktni odnosno indirektni korisnik javnih sredstava;

- Pravna lica kod kojih direktni odnosno indirektni korisnici imaju učešće u kapitalu odnosno u upravljanju;

- Pravna lica koja su osnovala pravna lica u kojim država ima učešće u kapitalu odnosno u upravljanju;

- Pravna i fizička lica koja primaju od Republike, teritorijalnih autonomija i lokalnih vlasti dotacije i druga bespovratna davanja ili garancije;

- Subjekti koji se bave prihvatanjem, čuvanjem, izdavanjem i korišćenjem javnih rezervi;

- Političke stranke, u skladu sa zakonom kojim se uređuje finansiranje političkih stranaka;

- Korisnici sredstava EU, donacija i pomoći međunarodnih organizacija, stranih vlada i nevladinih organizacija;

- Ugovorna strana u vezi sa izvršenjem međunarodnih ugovora, sporazuma, konvencija i ostalih međunarodnih akata i

- Drugi subjekti koji koriste sredstva i imovinu pod kontrolom i na raspolaganju Republike, teritorijalnih autonomija, lokalnih vlasti ili organizacija obaveznog socijalnog osiguranja.

Narodna banka Srbije je subjekt revizije, za koji je Državna revizorska institucija u obavezi da svake godine dostavi izveštaj o pravilnosti poslovanja Narodne banke Srbije u delu koji se odnosi na korišćenje javnih sredstava. Shodno odredbama zakona kojim se uređuje budžetski sistem, devizna sredstva korisnika budžetskih sredstava Republike, sredstava organizacije obaveznog socijalnog osiguranja i sredstava budžeta lokalne vlasti mogu se držati samo kod Narodne banke Srbije, tako da je poslovanje ovog subjekta od posebnog značaja.

Javna preduzeća, privredna društva i druga pravna lica koje je osnovao direktni, odnosno indirektni korisnik javnih sredstava, pravna lica kod kojih direktni, odnosno indirektni korisnici imaju učešće u kapitalu, odnosno u upravljanju i pravna lica koja su osnovala pravna lica u kojima država ima učešće u kapitalu, odnosno u upravljanju, su takođe subjekti revizije.

Revizijom mogu biti obuhvaćena bespovratna davanja ili garancije, subjekti koji se bave prihvatanjem, čuvanjem, izdavanjem i korišćenjem javnih rezervi, političke stranke, korisnici sredstava 
Evropske unije, donacija i pomoći međunarodnih organizacija, stranih vlada i nevladinih organizacija i drugi subjekti koji koriste sredstva i imovinu pod kontrolom i na raspolaganju Republike, teritorijalne autonomije, lokalnih vlasti i organizacija obaveznog socijalnog osiguranja.

Od 2015. godine Institucija sprovodi reviziju i odgovarajućeg broja parlamentarnih političkih stranaka na republičkom nivou, u skladu sa Zakonom o finansiranju političkih aktivnosti. Revizija se vrši i kod ostalih pravnih lica koja posluju sa subjektima revizije samo u pogledu njihovog poslovanja sa subjektima revizije. Postoji obaveza da Državna revizorska institucija svojim aktom bliže utvrdi način vršenja revizije kod ovih pravnih lica.

\section{EKSTERNA REVIZIJA}

Pod eksternom revizijom se podrazumeva postupak ispitivanja i ocene finansijskih izveštaja, na osnovu kojih se daje stručno mišljenje o realnosti i objektivnosti stanja imovine, kapitala, obaveza i rezultata poslovanja (Todorović i dr., 2015).

Konkretno, revizija finansijskih izveštaja predstavlja ispitivanje dokumenata, isprava, izveštaja i drugih informacija, radi prikupljanja dovoljnog, adekvatnog i pouzdanog dokaza za izražavanje mišljenja da li finansijski izveštaji subjekta revizije istinito i objektivno prikazuju njegovo finansijsko stanje, rezultate poslovanja i novčane tokove, u skladu sa prihvaćenim računovodstvenim načelima i standardima.

Revidiranje poslovanja prema Zakonu o Državnoj revizorskoj instituciji znači pribavljanje dovoljnog, adekvatnog i pouzdanog dokaza za izražavanje mišljenja o pravilnosti i svrsishodnosti poslovanja korisnika javnih sredstava. Revizija pravilnosti poslovanja znači ispitivanje finansijskih transakcija i odluka u vezi sa primanjima i izdacima, radi utvrđivanja da li su odnosne transakcije izvršene u skladu sa zakonom, drugim propisima, datim ovlašćenjima, i za planirane svrhe.

Revizija svrsishodnosti poslovanja znači ispitivanje trošenja sredstava iz budžeta i drugih javnih sredstava, radi sticanja dovoljnog, adekvatnog i pouzdanog dokaza za izveštavanje da li su sredstva od strane subjekta revizije upotrebljena u skladu sa načelima ekonomije, efikasnosti i efektivnosti kao i u skladu sa planiranim ciljevima (Andrić i dr, 2004).

Za razliku od eksterne dalje, interna revizija je nezavisna funkcija ustanovljena unutar organizacije koja ispituje i procenjuje njene aktivnosti. Svrha interne revizije je pomoć članovima organizacije, a posebno pomoć upravi u delotvornom ispunjavanju njihovih obaveza i odgovornosti, snabdevajući je analizama, procenama, preporukama, savetima i informacijama koje se odnose na aktivnosti organizacije. Delokrug rada interne revizije je važan i sa stanovišta revizije finansijskih izveštaja. Tu činjenicu potvrđuje postojanje Međunarodnog standarda revizije 610 - „Korišćenje rezultata rada interne revizije". Delokrug rada interne revizye je prvenstveno namenjen rukovodstvu preduzeća. Eksterni revizori finansijskih izveštaja mogu se koristiti radom interne revizije ako procene da im je ona od koristi.

Revizor u postupku planiranja revizije treba da proceni aktivnost interne revizije kako bi mogao efikasno pristupiti obavljanju revizije. Izvesne delove rada interne revizije revizor može koristiti u svom izveštaju.

Za kvalitet revizije od presudnog značaja je njena nezavisnost, koja mora biti institucionalizovana kroz adekvatnu organizacionu strukturu i propise.

U ovom tekstu je opisan postupak koji Državna revizorska institucija (Institucija) Srbije primenjuje prilikom izvođenja revizije. Tekst predstavlja rezime postupka detaljno opisanog u članovima 35. do 42. Zakona o Državnoj revizorskoj instituciji (Zakon) i članovima 10. do 42. Poslovnika Državne revizorske institucije (Poslovnik).

Institucija obavlja reviziju na osnovu godišnjeg programa revizije, koji je dužna da usvoji pre kraja godine za narednu kalendarsku godinu.

Godišnji program revizije donosi Savet Institucije na osnovu utvrđenih kriterijuma za izbor subjekta revizije.

U okviru koji postavlja zakon, Institucija samostalno odlučuje o subjektima revizije, predmetu, obimu i vrsti revizije, vremenu početka i trajanja revizije, ako Zakonom nije drukčije određeno.

Program revizije obavezno svake godine obuhvata:

1)budžet Republike Srbije;

2)organizacije obaveznog socijalnog osiguranja;

3)odgovarajući broj jedinica lokalne samouprave;

4)poslovanje Narodne banke Srbije koje se odnosi na korišćenje javnih sredstava;

5)odgovarajući broj javnih preduzeća, privrednih društava i drugih pravnih lica koje je osnovao direktni odnosno indirektni korisnik javnih sredstava i kod kojih ima učešće u kapitalu odnosno upravljanju.

Tokom kalendarske godine, Institucija može da izmeni i dopuni program revizije. Radi izvršenja programa revizije, Institucija može da angažuje revizore državnih revizorskihinstitucija drugih zemalja, kao i komercijalna preduzeća za reviziju. 
Za izvršenje svog programa revizije, Institucija može da koristi izveštaje o izvršenoj reviziji koje su izdala komercijalna preduzeća za reviziju, odnosno na osnovu tih izveštaja da planira dodatne postupke kod subjekata revizije, s tim što je Institucija odgovorna za konstatacije revizije i kada koristi navedene izveštaje.

Pre početka revizije nadležni vrhovni državni revizor može podneti subjektu revizije zahtev za podnošenje podataka, koji su mu potrebni u planiranju i izvođenju revizije.

To je, u principu, spisak knjigovodstvene i/ili druge dokumentacije koju poseduje subjekt, koja je potrebna revizoru. Ovaj zahtev je pojačan upozorenjem da će u slučaju njegovog neispunjenja biti podneta prijava za prekršaj.

Postupak revizije počinje zaključkom o sprovođenju revizije, koji donosi generalni državni revizor na osnovu programa revizije, koji je doneo Savet Institucije. Ovo je prilično formalan dokument u kome se navodi ko će biti revidiran, šta će se revidirati, ciljevi revizije i koji će se period obuhvatiti revizijom. U toku samog postupka revizije ovaj zaključak može biti dopunjen (proširen obim revizije, promenjen period koji će biti obuhvaćen revizijom itd.).

Subjekt revizije može podneti prigovor na ovaj zaključak, a o prigovoru odlučuje Savet Institucije, koji ga može odbaciti, odbiti ili prihvatiti kao osnovanog. Generalni državni revizor izdaje ovlašćenje licu koje će vršiti reviziju. To lice sprovodi postupak revizije čiji cilj je prikupljanje dovoljno odgovarajućih dokaza za formiranje mišljenja o poslovanju subjekta revizije. Ako u toku revizije budu otkrivene radnje ili dokumenta koja ukazuju na mogućnost postojanja krivičnog dela ili prekršaja, revizor tu dokumentaciju može zapleniti, ali ne duže od osam dana.

Ako u postupku revizije subjekt revizije ne ispolji odgovarajuću spremnost na saradnju, generalni državni revizor izdaje nalog za podnošenje isprava (koje su mu potrebne, a nisu dostupne), koji sadrži i upozorenje da u slučaju njegovog ne izvršenja može biti podneta prijava za prekršaj.

Izveštaj o reviziji sastavlja se u pisanom obliku u formi nacrta, predloga i izveštaja kojim se okončava postupak revizije. Izveštaj sadrži elemente predviđene Međunarodnim standardima revizije. Nacrt i predlog izveštaja su poverljivi.

Nacrt izveštaja o reviziji sastavlja se nakon obavljene revizije i uručuje subjektu revizije. Subjekt revizije ima pravo da, u roku od 15 dana od dana uručenja izveštaja, podnese obrazloženi prigovor. Nadležni vrhovni državni revizor razmatra opravdanost primedbi u roku od 15 dana od dana prijema prigovora. O prigovoru na nacrt izveštaja može se raspravljati i na sastancima (može ih biti više) koji organizuje vrhovni državni revizor i na koji poziva subjekte revizije. Svrha sastanka je otklanjanje nesaglasnosti i eventualno podnošenje novih dokaza.

Sastanak je vrlo formalnog karaktera, otpočinje pozivom i vodi se zapisnik o njegovom toku. Više članova Poslovnika regulišu tok tog sastanka i moguće situacije u toku njegovog održavanja.

Nakon poslednjeg sastanka na kome se raspravljalo o nacrtu izveštaja (može ih biti više), vrhovni državni revizor sastavlja predlog izveštaja o reviziji i uručuje ga subjektu revizije (i odgovornom licu, sadašnjem i/lii pređašnjem) u roku od 30 dana od dana održavanja poslednjeg sastanka na kome se vodila rasprava o nacrtu izveštaja o reviziji.

Predlog izveštaja o reviziji uručuje se i članovima Saveta Institucije. Subjekt revizije može, u roku od 15 dana od dana njegovog prijema, podneti prigovor na predlog izveštaja o reviziji sa navođenjem razloga i činjenica za njegovo osporavanje. O ovom prigovoru odlučuje Savet Institucije, u roku od 30 dana od dana njegovog prijema, a odgovor dostavlja subjektu revizije zajedno sa konačnom verzijom izveštaja o reviziji.

Savet može doneti zaključak da se:

- sporni nalaz izostavi iz izveštaja o reviziji,

- sporni nalaz ostane sastavni deo izveštaja u neizmenjenom obliku,

- sporni nalaz ostane sastavni deo izveštaja sa sadržinom koju odredi Savet.

Ako je potrebno, generalni državni revizor može odrediti da se o pojedinim delovima predloga izveštaja pribavi mišljenje spoljnog stručnjaka.

Izveštaj o reviziji donosi generalni državni revizor. Taj izveštaj ne može da sadrži nalaze revizije koji nisu sadržani u nacrtu, odnosno predlogu izveštaja o reviziji. Pre njegovog izdavanja vrši se pravno tehnička redakcija izveštaja.

U toku revizije vodi se računa o tome da li pojedine radnje subjekta revizije imaju obeležja prekršaja ili krivičnog dela. U tom slučaju generalni državni revizor, bez odlaganja, podnosi zahtev za pokretanje prekršajnog postupka, odnosno krivičnu prijavu, nadležnom organu.

Subjekt revizije u čijem su poslovanju bile otkrivene nepravilnosti ili nesvrsishodnosti koje nisu otklonjene u toku obavljanja revizije, dužan je da ih otkloni u roku od 30 do 90 dana od dana uručenja izveštaja o reviziji i o tome podnese izveštaj Institucije (odazivni izveštaj). U suprotnom podnosi se prijava za prekršaj protiv njega.

Institucija, može, da izvrši kontrolu navoda u odazivnom izveštaju o čemu sastavlja poslerevizioni izveštaj. U slučaju nezadovoljavajućih nalaza upućuje se zahtev odgovarajućem organu da preduzme mere protiv subjekta revizije (podnošenje prijava, predlog za razrešenje odgovornog lica itd.).

Odazivni izveštaj je javna isprava. 
Institucija vrši sledeće vrste revizije:

- Reviziju finansijskih izveštaja - ispitivanje dokumenata, isprava, izveštaja i drugih informacija, radi prikupljanja dovoljnog, adekvatnog i pouzdanog dokaza za izražavanje mišljenja da li finansijski izveštaji subjekta revizije istinito i objektivno prikazuju njegovo finansijsko stanje, rezultate poslovanja i novčane tokove, u skladu sa prihvaćenim računovodstvenim načelima i standardima;

- Reviziju pravilnosti poslovanja - ispitivanje finansijskih transakcija i odluka u vezi sa primanjima i izdacima, radi utvrđivanja da li su odnosne transakcije izvršene u skladu sa zakonom, drugim propisima, datim ovlašćenjima, i za planirane svrhe;

- Reviziju svrsishodnosti poslovanja - ispitivanje trošenja sredstava iz budžeta i drugih javnih sredstava, radi sticanja dovoljnog, adekvatnog i pouzdanog dokaza za izveštavanje da li su sredstva od strane subjekta revizije upotrebljena u skladu sa načelima ekonomije, efikasnosti i efektivnosti kao i u skladu sa planiranim ciljevima.

\section{ZAKLJUČAK}

U uslovima globalizacije, te sveobuhvatnih i značajnih promena na tržištu, Državna revizorska institucija izdvaja se kao bitan segment u poslovanju državnih ustanova i institucija. Ona je usmerena ka ispitivanju finansijskih izveštaja s ciljem izražavanja mišljenja o njihovoj realnosti i objektivnosti. U svom radu koristi brojne metode i pri tome se rukovodi računovodstvenim standardima, načelima, pravilima i slično.

Bez obzira na kratku istoriju postojanja Državne revizorske institucije u Republici Srbiji, ona je na našem području dala značajan doprinos efikasnom poslovanju. Osnovni zadatak i cilj DRI je zaštita interesa vlasnika kapitala tako da svojom nepristranošću daje mišljenje o realnosti i objektivnosti finansijskih izveštaja i održavanja sigurnosti odvijanja poslovnog procesa.

Relevantne činjenice koje DRI čine bitnim segmentom međunarodnog korporativnog upravljanja su nepristranost, objektivnost, sveobuhvatnost, racionalnost, pouzdanost i slično. U obavljanju poslova revizije primenjuju se opšteprihvaćena računovodstvena načela, te računovodstveni standardi, odnosno smernice revizije.

Mehanizmi koji osiguravaju efikasnost korporativnog upravljanja su raznovrsni, a jedan od važnijih je eksterna revizija koja u svakodnevnoj praksi dobija sve veće značenje. Može se i reći da je ona postala neodvojivi deo dobre prakse korporativnog upravljanja.

Odnosi Državne revizorske institucije i subjekata revizije pokazuju da eksterna revizija koju sprovodi DRI, kao meru verodostojnosti finansijskih izveštaja, doprinosi kvalitetu finansijskih izveštaja, ali i njihovoj korisnosti u korporativnom upravljanju. Takođe je izuzetno je važna i komunikacija eksterne i interne revizije kao dva temeljna i najznačajnija segmenta celokupne revizijske profesije. Između njih postoje određene sličnosti, ali i neke bitne razlike. Postupak eksterne revizije koju sprovodi DRI uvek započinje s upoznavanjem, proverom i ocenom pouzdanosti internih kontrola i na temelju toga se određuje reprezentativni uzorak pomoću kojeg će se testirati podaci iz finansijskih izveštaja kako bi se ocenile njihova objektivnost i realnost.

Zahvaljujući pouzdanosti revizorskih izveštaja te ostalih navedenih činjenica eksterne revizije, vrlo je lako moguće da će se interes za uslugama revizora samo proširivati u bliskoj budućnosti.

\section{LITERATURA}

1. Andrić, M., Krsmanović, B. i Jakšić, D.: Revizija, teorija i praksa, četvrto izmenjeno i dopunjeno izdanje, Subotica, 2004

2. Todorović, M., Vučković Milutinović, S.: Revizija, Ekonomski fakultet, Beograd, 2015;

3. http://www.dri.rs/upload/documents/Opsti_dokumenti/zakon_dri.pdf

4. http://www.apeiron-uni.eu/lycboardclient/Default.aspx?DepartmentID=9\&NewsID=14657

5. Ustav Republike Srbije, 2006. godina;

6. Zakon o Državnoj revizorskoj instituciji ("SI. glasnik RS", br. 101/2005, 54/2007 i 36/2010);

7. Zakon o budžetskom sistemu (Službeni glasnik RS“, br. 54/09, 73/10, 101/10, 101/11 i 93/12);

8. Zakon o finansiranju političkih aktivnosti ("SI. glasnik Republike Srbije", br. 43/11 i 123/14);

9. Poslovnik Državne revizorske institucije ("Sl. glasnik RS", br. 9/2009);

The State Audit Institution (Institution) is the highest organ of the audit of public funds in the Republic of Serbia. Established in 2005, the Law on State Audit Institution. The State Audit Institution is an autonomous and independent state authority. To perform activities within its jurisdiction Institution is 
responsible to the National Assembly of the Republic of Serbia. Activities within its jurisdiction performs on the basis of the Constitution of the Republic of Serbia, the Law on State Audit Institution and the State Audit Institution, which in accordance with the law, specify the manner and procedure for the exercise jurisdiction Institution audits way of ensuring transparency, decision making and other issues established law that are relevant to the work of the Institution. The institution has a president of the Institution, Vice President, Council, audit departments and support services.

Key words: The State Audit Institution, revision, code of ethics of state auditors.

Rad primljen: 08.09.2015.

Rad prihvaćen: 23.01.2016. 